Paideusis

\title{
"Liberating Praxis: Paulo Freire's Legacy for Radical Education and Politics" (Peter Mayo)
}

\section{Karen Sihra}

Volume 15, Number 2, 2006

URI: https://id.erudit.org/iderudit/1072686ar

DOI: https://doi.org/10.7202/1072686ar

See table of contents

Publisher(s)

Canadian Philosophy of Education Society

ISSN

0838-4517 (print)

1916-0348 (digital)

Explore this journal

Cite this review

Sihra, K. (2006). Review of ["Liberating Praxis: Paulo Freire's Legacy for Radical Education and Politics" (Peter Mayo)]. Paideusis, 15(2), 109-113.

https://doi.org/10.7202/1072686ar 
Review of

\title{
Liberating Praxis: Paulo Freire's Legacy for Radical Education and Politics
}

by Peter Mayo, Westport CT: Praeger Publishers, 2004. ISBN 0-89789-786-2

\author{
KAREN SIHRA \\ University of Toronto, Canada
}

\section{Overall Summary}

In Liberating Praxis: Paulo Freire's Legacy for Radical Education and Politics, Peter Mayo weaves together Freire's English language text, Freire's work and experiences in the field, and interpretations of Freire's work to present a succinct presentation of Freire's educational theory. Illustrating the diversity in Freire's own work, Mayo shows the utility and malleability of Paulo Freire's work in a modern multicultural context, namely the Mediterranean. Mayo's main argument is that Freire's work, as it is represented here, has the capacity to function in a variety of contexts and settings and therefore is not culturally specific.

\section{Chapter Summary}

In chapters one, two and three Mayo successfully prepares the reader with Freire's philosophy for his subsequent discussion of Freire's work in the Mediterranean. The most insignificant characteristic of these chapters is that Mayo says nothing that cannot be found elsewhere in work by or on Freire; it is the presentation of these ideas that is consequential.

Chapter one, entitled "Paulo Freire: The Educator, His Oeuvre, and His Changing Contexts," introduces Freire's life, work, and politics in general. It provides a broad overview of Freire's life and influences, the challenges of translating his work from Portuguese to English and how much is lost in translation, and a personal reflexive statement that positions Mayo as a supporter of Freire's work.

In chapter two, Mayo provides an analysis of works written on Freire's thought. He is indeed critical, as the title "Holisitc Interpretations of Freire's Work: A Critical Review" implies, of the interpretations of Freire's work, recognising theoretical and practical faults in the work. For example, despite Mayo's appreciation of Maria Del Pilar O'Cadiz, Pia Lindquist Wong, and Carlos Alberto Torres' Education and Democracy: Paulo Freire, Social Movements, and Educational Reform in Sao Paulo (1998), Mayo recognises the limitations of their work. For example, he shows the way their resources and interviews favour "teachers" voices, and perhaps the study could have been enhanced with more thick descriptions from field notes..." (p. 28). This is just one instance where Mayo recognises the significance and contribution of a text, yet is able to recognise its shortcomings. Other work reviewed in this chapter include Paul V. Taylor's The Texts of Paulo Freire (1993), Moacir Dadotti's Reading Paulo Freire (1994), and John L. Ellias' Paulo Freire: A Pedagogue of Liberation (1994).

(C) Copyright 2006. The author, Karen Sibra, assigns to Paideusis the right of first publication and educational and non-profit institutions a non-exclusive license to use this document for personal use and in courses of instruction provided that the article is used in full and this copyright statement is reproduced. Any other usage is probibited without the express permission of the author. 
Providing these insights into works already completed on Freire, Mayo turns his attention to Freire's own theoretical and experiential work. Chapter three, entitled "Critical Literacy, Praxis, and Emancipatory Politics," is a dense chapter that dives into Freire's framework around a variety of central themes. For example, Mayo shows how critical literacy can work against "banking" education and traditional manifestations of authority. He also shows the ways critical literacy together with conscientizacao has the capacity to promote the type of praxis and emancipatory politics Freire advocates. He does this by not only looking at texts by Freire and other's interpretations of this work; Mayo looks at the work Freire did in the world, and shows how his roles in educational departments, politics, and government institutions influenced his work. In this way, Mayo adds to existing literature through connecting works in a practical and applicable way.

The majority of work presented in these first few chapters draws on the work of Freire before the 1990s. Chapter four, entitled "Remaining on the Same Side of the River': Neo-Liberalism, Party, Movements, and the Struggle for Greater Coherence" explores the English language work of Freire in the 1990s; Mayo argues that these works are "characterized by too much repetition" (p. 74). Mayo does, however, explain the ways Freire's work in the field influenced his writings, providing a detailed history and analysis of the movements with which Freire associated, namely Partido dos Trabalhadores (PT Workers' Party), and the Movimentos dos Trabalhadores Rurais Sem Terra (MST), and his work as a founding member of both organizations.

In addition to showing Freire's political activism, Mayo discusses the later works of Freire, namely Pedagogy of Hope and Letters to Cristina, arguing that these are largely autobiographical works yet "provide the reader with an expanded and often detailed knowledge of the concrete contextual background regarding the development of Freire's ideas" (p. 78). Fortunately for the reader, Mayo is explicit about what is new in these works, outlining the ways in which Freire clarified many of his positions and reformulated existing ideas, arguing that Freire probably did this to clarify misconceptions of his work. For example, Freire's belief in a delicate balance between freedom and authority is often misinterpreted to imply a laissez-faire pedagogy. To this misinterpretation, Mayo shows, Freire reiterates the role of the teacher and the authority the teacher possess as a result of knowledge they have of the subject they teach. He insists that authority derived from knowledge need not lead to authoritarianism. In addition, Freire used his later work, Mayo argues, to reiterate key themes that are central to his overall pedagogical scheme. For example, Mayo highlights love and humility as recurring themes, love becoming even more significant in Freire's overall thought as his work progresses.

It is in chapter five and six that Mayo provides the most significant original insight into Freire's work and the uses of it. In chapter five, entitled "Reinventing Freire in a Southern Context: The Mediterranean" he shows the ways in which Freire's work is indeed not a "one shoe fits all strategy, which has been a feature of the dominant neoliberal, neo-colonial, and technical rational discourse in education" (p. 103). Through showing the success of applying Freirian concepts to a diverse population that Freire never directly addressed, Mayo shows the ways Freire translates into different contexts. Mayo maps Freire's context onto his own Mediterranean context to show the ways in which Freire's thought can address calls for learning about the other, inclusive language, and multicentric curriculum.

Chapter six, "Engaging with Practice: A Freirian Reflection on Different Pedagogical Sites" also draws on Mayo's personal experience and demonstrates the ability of Freire's work to move beyond conventional educational settings. He emphasises the importance of "working outside the academy's hallowed walls" (p. 130) while recognising the importance of working within the system. Working outside these walls draws on a variety of what he terms stakeholders, such as parents, local councils, and school councils. Mayo shows the value of calling for a "development of the museum and other centers as democratic public spaces that allow possibilities for different meanings to be exchanged, appropriated, and negotiated" (p. 145).

In sum, Mayo's overall project attempts to demonstrate the relevance of Paulo Freire's work in different educational settings and contexts. He successfully provides the reader with significant 
background to show how this is the case in a Mediterranean context. It is a valuable book insofar as it adds to the diversity of literature on Freire's significance in the 21 st century.

\section{Critique}

Yet, the problem lies with the book's attempt to create a legacy. Most notably in chapter three, Mayo falls into the trap of idealizing Freire. Mayo's need to overlook Freire's shortcomings, and make excuses for the lack of a piece of a logical puzzle are littered throughout the book.

One such example of this is Mayo's handling of Freire's use of the word tolerance. He argues that "tolerance... strikes me as being a trifle condescending when used in English, and I would much prefer the term solidarity... Solidarity became an important issue in Freire's writings in the late 1980s and 1990s, which stress the need for persons to gain greater coherence throughout life" (p. 93). Mayo's renaming of terms highlights a theme common in many works on Freire.

Kathleen Weiler provides a convincing argument explaining why these types of liberties are taken with Freire's work. She argues that Freire had a "tendency toward inspirational but decontextualized generalizations. His pronouncements frequently invoke universal themes such as justice, love, and freedom - terms that can be appropriated by writers from a number of different traditions" (Weiler, 1996, p. 363). It is the "lack of 'historical specificity"' (Weiler, 1996, p. 364) in Freire's work that allows Mayo to interpret and re-interpret Freire's work in a way that is malleable and contextualised; hence the criticism has the capacity to serve as an asset to Mayo's argument. Unfortunately, despite his overall project, Mayo does not take the opportunity to explore these possibilities. His overall argument would be made stronger with a discussion of Freire's ability to use such "decontextualized generalizations," making it possible for his work to translate into a Mediterranean context.

Mayo ensures that the reader knows that he knows a critical gaze, such as the one offered by Weiler, toward Freire's work exists. He is willing to provide us with a brief description and reference to these critiques. However, the problem lies in the way Mayo addresses these critiques. For example, Mayo argues:

For Freire, teachers were not to be regarded as coddling aunts or mothers - professora sim, tia nao... which when translated, reads: teacher yes, aunt no... Unfortunately, Freire raised this issue without any engagement on his part in a critique of the normalizing discourse regarding women's role in the family, generated by and supporting the existing patriarchal structures of economic oppression...

This having been said, one must appreciate the main reason that motivated Freire's writing of this book [Teachers as Cultural Workers], which was meant as an attack on what was then an emerging ideology in Brazil intended to deprofessionalize teachers by suggesting that they be called "aunties" by the children in their care... The implicit message was: "how can you go on strike if you are aunties and the children are your nephews and nieces? (Freire, 1995, p. 17)." (p. 85).

Mayo provides a relatively reasonable explanation of Freire's use of gendered language, but he fails to recognise the critique for what it is, namely the problem with Freire's normalizing discourse. Despite his own recognition of the problem of normalizing discourse, he appeals to the political to justify Freire's word-choice without addressing what such affect such terminology has on Freire's overall position. Again, Weiler provides a convincing argument of why this is the case. She argues that many who write on Freire speak on behalf of Freire (Weiler, 1996, p. 364). She points to those who offer a more sympathetic reading of Freire, namely bell hooks, to show the importance of noting Freire's 'blind spots' while holding that a criticism of his work need not "lead us to discount the power 
of Freire's political stance" (Weiler, 1996, p. 367). Again, Mayo's lack of serious consideration of these critiques denies the potential depth of his overall project.

Interestingly, Mayo cites Weiler's (1991) early work on Freire, stating critiques such as hers are instrumental. Again, however, such critiques are addressed in a light that is unduly favourable to Freire and does not, in some ways, show the richness of Mayo's perspective. A brief example can be found in Mayo's discussion of Freire's talking books. He notes that bell hooks expressed desire to engage in a talking book with Freire but never did, for whatever reason. He argues that "the tensions likely to arise from these discussions could have helped stretch Freire's ideas with respect to these issues and could have possibly rendered his work, coauthored with significant other educators, even more insightful, instructive, and powerful in its analysis of the different forms of oppression" (p. 96). Mayo also discusses the limitations of talking books, and their lack of substantial conflict. Many of the exchanges in Freire's talking books were characterised by the authors' free movement from one topic to another without developing these topics in any significant depth. Given this characterization, the reader is left questioning (1) whether this is a meaningful medium to address intersections of oppressions, and (2) why Freire never embraced such conflict in his talking books, despite the willingness of his colleagues. Mayo addresses neither of these questions.

I would further question, when Freire does not take seriously the intersection of oppressions, what does this do to his philosophy of/for the oppressed? Mayo is in an ideal position, given the format of the book and the context in which he writes to address seriously this type of question.

\section{Freire's Unfinishedness}

Weiler argues that "Freire's own pedagogy calls for a profoundly critical way of being in the world... his use as a symbol without an active and critical engagement with his thought, seems to me a betrayal of the ideals he is calling for in his best work" (Weiler, 1996, p. 354). I would like to focus in this section on just one theme in Freire's work that shows how Weiler can make such a claim, namely his concept of unfinishedness. I will then return to Mayo's work to show the ways taking the concept of unfinishedness into account actually adds value to Mayo's overall project of showing the malleability of Freire's work.

In Pedagogy of Freedom Freire argues "... I hold that my own unity and identity, in regard to others and to the world, constitutes my essential and irrepeatable way of experiencing myself as a cultural, historical, and unfinished being in the world, simultaneously conscious of my unfinishedness" (Freire, $1998 / 2001$, p. 51), and goes on to say "I like to be human because in my unfinishedness I know that I am conditioned. Yet conscious of such conditioning, I know that I can go beyond it, which is the essential difference between conditioned and determined existence" (p. 54). Without searching for further evidence, it is clear that Freire believes that neither he nor his philosophy is complete.

In his discussion of unfinishedness, Freire argues that we need others and relationships with others that will allow us to see how we are incomplete beings, and reliant on others to create our realities. Not only is it an awareness of our unfinishedness that makes us educatable, but more importantly, it is our unfinishedness that makes us educatable. This is especially true when we look at the way Freire wants us to understand learning, namely through others, and as a constant process. "The unfinishedness of our being" implies that there is something that needs to be learned from something not within ourselves. To do this, we must first move away from our conception that we can really "know" anything outside of what we learn from others.

To infer, as I believe Mayo does through his handling of the critiques of Freire, that Freire is unwilling to apply unfinishedness to his own work denies him the very principles he wishes to apply to both the word and the world. Unnecessarily, Mayo presents Freire's work as a complete treatise despite his demonstration through his examples of successful work in the Mediterranean that incorporates 
many of the critiques of Freire's work. One example that Mayo describes is especially significant in this discussion.

Mayo draws on his experience as a member of a coordinating team for a parent empowerment project in a state primary school in one working class locality of Malta. The group's commitment was to forge a partnership between parents and the state primary school. Membership in this project included members of the School Council and at least one mother of a child attending the school. At the first meeting of parents and the coordinating team, fifty parents were in attendance, all of whom were women. Mayo's team determined the theme of the first meeting, and instigated a Freirian approach that provided a mixture of teaching and dialogue. The women determined the theme of subsequent meetings. The meetings were anchored by one of the coordinators or a guest resource person to ensure that the "sessions do not degenerate into examples of laissez-faire pedagogy" (p. 133). As a result, the discussions addressed the particular concerns of mothers/female guardians within the community while being directive. The concerns addressed became those that connected with the women's "thematic universe" (p. 132). These concerns eventually led to an identification of issues and concrete action.

Mayo presents a number of theoretical questions that emerged out of this "socially committed action research, a form of praxis" (p. 133). These questions include: "On whose terms is the partnership carried out? To what extent are the social relations involved genuinely democratic, that is to say, involving a two-way flow of ideas for action, as opposed to being hierarchical?" (p. 133). Mayo does show the ways Freire's philosophy successfully maps onto non-class based movements, but he does not ask questions about the implication of women's activism in the public sphere, how this experience changes the face of Freire's work, and, most importantly for his overall argument, the malleability of Freire's work. Not asking these types of questions has the capacity to discredit the core of Freire's critical pedagogy overall, and his concept of unfinishedness specifically. Furthermore, Mayo has the opportunity to make a larger theoretical contribution to the field than what is taken up here, showing the ways in which those that Freire does not specifically address can successfully use his work, and the implications of this use on Freire's overall philosophy.

\section{Conclusion}

In sum, while Mayo's book is useful as it presents Freire's work in a multifaceted way, addressing the theoretical and experiential elements, and presents a variety of different successful projects in diverse contexts to show its malleability, he stops short, however, of delving in detail into the 'blind spots' in Freire's work-'blind spots' that have the capacity to contribute, rather than impair, his effort to create a legacy of Freire's work. A discussion by Mayo that included an integration of his work in the world with the 'unfinishedness' of Freire's thought, and the contributions his work makes to Freire's overall theoretical framework would prove invaluable to the study of successful Freirian initiatives.

\section{References}

Freire, P. (1995). The progressive teacher. In M. de Figueredo-Cowan and D. Gastaldo (Eds.), Paulo Freire at the institute (pp. 61-67). London UK: Institute of Education/University of London.

Freire, P. (1998/2001). Pedagogy of freedom: Ethics, democracy, and civic courage. Oxford: Rowman \& Littlefield.

Mayo, P. (2004). Liberating praxis: Paulo Freire's legacy for radical education and politics. Connecticut: Praeger Publishers.

Weiler, K. (1991). Freire and a feminist pedagogy of difference. Harvard Educational Review, 61, 449-474.

Weiler, K. (1996). Myths of Paulo Freire. Educational Theory, 46 (3), 353-371. 